\title{
Evaluation of Quality of University Education Exemplified by the Faculty of Physical Culture, Palacký University, Olomouc
}

\author{
Iva Dostálová, Zbyněk Svozil, Martin Sigmund, \\ Jana Kvintová, Jan Baše
}

\begin{abstract}
Evaluation can be understood as a process of collecting and assessing empirical data in a context of theoretical background in order to gain practice-relevant information and data. The purpose of educational evaluation is to provide assessment of the whole educational reality. This is not merely testing educational outcomes but a much wider reflection of educational phenomena that serves both research-based and practical purposes. The evaluation process of university education in the Czech Republic does not match with most developed countries in terms of quality and number of research studies. In the long term, the development of the whole educational system cannot do without thorough scientific evaluation research studies that give evidence of the real state of education but can provide theoretical background and basis for practical measures. During the past several years Czech education has gradually been pervaded by an 'evaluation atmosphere'. This is indicated both by official educational policy documents and specific research studies into measuring educational outcomes or comparing the production of state and private schools, etc. This paper presents an overview of the issue of educational evaluation in universities and its theoretical background,
\end{abstract}


including a specific example of an evaluation process performed in one of the Faculties of Palacký University, Olomouc.

Key words: Assessment, educational work, education, teachers, university students.

\section{Introduction}

The Czech Republic does not reach the level of most developed countries in terms of number and quality of evaluation research studies. This is primarily due to neglecting this issue in the past decades, during which educational policy ideologists showed no interest in educational evaluation. Another cause is the fact that, contrary to other countries, current educational research in the Czech Republic has not addressed the needs of educational policy, particularly in the area of evaluation.

In order to change the situation in the area of educational evaluation it would be necessary to change the attitudes of stakeholders in education so that they accept and require evaluation analyses and research studies, and to teach educators active in the educational process and students of teacher courses to use educational evaluation tools, understand those tools, and also to provide institutional conditions for the scientific field of 'educational measurement and evaluation' as is usual in foreign countries.

During the past several years an'evaluation atmosphere' in education has gradually been developed in the Czech Republic. This is indicated both by official educational policy documents and specific probes and research studies into measuring educational outcomes or comparing the production of state and private schools, etc. Another positive signal is that there are certain initiatives by some institutions and individuals to encourage evaluation activities. For example the Research Institute of Education in Prague has held regular seminars aimed at various topics of educational evaluation since 1995 (Průcha, 1996). "The missing methodology has been finally developed within the Quality to Schools project - use of objective quality management systems in the work and evaluation of schools, whose aim was to introduce a functional quality management system into the process of internal and external educational evaluation" (Perspektivy kvality, 2009).

\section{Objective}

The objective of the present paper is to provide an overview of the issue of educational evaluation in universities and its theoretical background, including an example of an evaluation process performed at the Faculty of Physical Culture, Palacký University, Olomouc. 


\section{Evaluation and assessment}

The term evaluation is relatively new in the Czech language. The origin of the term comes from the Latin verb 'valere', which means be strong, valid, serious. From Latin the word was transferred to English as 'evaluation', and means to set a general value (Nezvalová, 2006).

The definitions of the terms 'assessment' and 'evaluation' are necessary for their correct understanding. In a general context, both terms are synonymous, i.e. identical or very close in meaning. In professional educational terminology (both Czech and foreign) there are subtle differences in the way both terms are used. As stated by Prúcha (1995), evaluation covers a wider comprehensive meaning, i. e. evaluation summarizes the theory, methodology and practice of evaluating various educational phenomena. It is a professional term in scientific and research communication. Průcha $(2000,124)$ also clarifies the term of educational evaluation as an "educational discipline dealing with evaluating the phenomena of educational reality. This is a very wide range of evaluated areas; evaluation can cover virtually anything related to schools and their activities."

In English terminology the term 'evaluation' has a more complex meaning, and is used more often in research contexts. 'Evaluation' is a term introduced in the area of the theory of science and research. On the contrary, the term 'assessment' is rather used in the context of usual school practice, particularly with respect to assessing certain educational subjects, for example pupil assessment, teacher assessment, etc. There is also a concept however, in which 'assessment' is viewed as systematic collection of information and formulating conclusions about the knowledge and skills of a student and the quality and successfulness of education, as stated by Scriven (1991).

Nezvalová (2006) according to Bennet explains evaluation as a process of systematic collection and analysis of information according to certain criteria for the purposes of further decision making. This definition indicates that evaluation should:

- Be systematic, i.e. explicitly defined area and structure;

- Follow appropriate methodology;

- Be carried out regularly;

- Follow predetermined criteria;

- Be applicable in decision making and further planning (Nezvalová, 2006).

There are two types of evaluation: internal and external. Internal evaluation is commonly called self-evaluation and focuses on evaluating internal processes. The aims as well as methods, forms and measures of internal evaluation are set by the subject itself (individual or school).

External evaluation applies to overall functioning of the system. The aims are set from the outside, the measures and criteria are specified by the evaluator. The subject of external evaluation is usually the school. External evaluation is commonly performed 
by the school inspectorate, school authority or by evaluation institutes such as Cermat, Scio, Kalibro, in foreign countries school evaluation is sometimes ordered by the parents. A disadvantage of external evaluation might be that the core of the problem is not sufficiently analysed and not all causes of the monitored phenomena are covered. Also, the irregular nature of external evaluation does not cover long-term development (Rýdl, Horská, Dvořáková and Roupec, 1998).

The term educational monitoring implies continuous data-based informing of the educational policy sphere and the public about the general conditions, course characteristics, results and benefits of educational processes. Monitoring is understood as long-term observation of a certain system, whose aim is to identify any changes and developmental trends. Monitoring is based upon collecting information and data on a regular basis and operates with indicators describing and assessing the system production or productivity. A key aspect is overcoming the limited perspective of individual participants. This fact is a precondition for systematic comparison (Janík, Knecht and Najvar et al., 2010).

Evaluation can be understood as a process of collecting and evaluating empirical data against a theoretical background in order to gain practice-relevant information and data. Evaluation research aims to gain information relevant to decision making and practical measures. Evaluation requires links established between empirical investigation and assessment based on norms, decision making and measures. Evaluation research thus produces three types of statements, i. e. experience-based statements, normative statements as a basis for assessment and prognostic statements with respect to future decision making and measures (Janík, Knecht and Najvar et al., 2010).

The term evaluation summarizes the theory, methodology and practice of all evaluation, it is a term used in the scientific area. On the contrary the term assessment is used in the context of usual school practice. Scriven (1991) states that the use of both terms is distributed according the respective field of activity: evaluation is a term used in the area of theory, science and research, whereas assessment is a term used by teachers, parents and non-educational public. The differences in the meanings of evaluation and assessment are truly subtle. From a semantic point of view there are almost no differences (there are only certain differences in the sphere of communication use), therefore, both terms can be used as synonyms in terms of their meaning. Foreign literature often includes a terminological expression 'evaluation and measurement'. This concept implies that in the context of evaluation research, measurement is the basic process. The meaning of both terms is very close, although the term measurement has a wider content in the field of education as it is a methodological means (Byčkovský, 1982). 


\section{Educational evaluation}

The purpose of educational evaluation is to provide evaluation information about the whole educational practice. This is not merely testing of educational outcomes but a much wider reflection of educational phenomena used for both research and practical purposes. Based on a subject perspective, Prücha (1996) defined the areas that present the subject of interest and investigation and create the subject field of educational evaluation. These areas include: evaluation of educational needs; evaluation of educational programmes; evaluation of educational environments; evaluation of educational outcomes; evaluation of educational effects; evaluation of schools or educational institutions; evaluation of alternative schools or alternative education; evaluation based on the indicators of the educational system; evaluation of educational science or research; evaluation of the educational process (learning and teaching) (Janík, Knecht and Najvar et al., 2010).

In an effort to comprehensively describe the term evaluation, it appears practical to define the term using a set of features as defined by Prücha (1996):

- Educational evaluation is primarily a theoretical approach. It is a concept, according to which all phenomena of educational reality (educational processes, their programmes and functioning, educational outcomes, educational institutions, etc.) can and must be assessed in specific ways.

- At the same time, educational evaluation is a methodology, i.e. a set of instruments (special methods and techniques) and professional conventions to apply these instruments for the purposes of realization of this approach.

- Educational evaluation is a process, i.e. a set of activities ensured by an institutional and organizational research infrastructure, which practically realizes the approach using appropriate methodology. This process is aimed at collecting and analysing data reflecting a condition or development of certain phenomena of educational reality, i.e. at monitoring and measurement of these phenomena.

- As a process, educational evaluation takes place at various levels of educational practice, from assessing individuals or individual educational programmes to evaluating national outcomes of the educational system or international evaluation of educational systems in multiple countries.

- Educational evaluation has various spheres of application, both for scientific and research purposes (theoretical explanation of the 'behaviour' of the phenomena of educational reality), and for practical purposes (provides a basis for the management of educational institutions, their financing, etc.) (Průcha, 1996).

These characteristics imply that educational evaluation is a very complex and multifaceted phenomenon quality-wise. In professional terminology the term 'evaluation' has a general meaning of 'assessment'. In education this term includes identifying, 
comparing and explaining data that describe the condition, quality, functioning and effectiveness of a school or an educational system or a part thereof. It further includes the assessment of educational processes, assessment of educational projects, assessment of educational outcomes, assessment of textbooks, etc. It plays a significant role in the process of revision and innovation of the educational system, it is important for planning strategies of its development, priorities, etc. It is an independent scientific discipline and is based upon a wide and thorough theoretical and methodological basis: educometry, effectiveness of education, evaluations of schools, IEA, Kalibro, comparative education, TIMSS (Průcha, Walterová and Mareš, 2003).

\section{Evaluation process}

Prior to evaluation Gard, Flannigan and Cluskey (2004) suggest that the evaluation team answer four important questions that will move the whole process forward. The questions are: what do we want to know; why do we want to know it; what should we measure; how should we measure it. In terms of developmental stages the evaluation process can be divided into six stages, which follow one after another and overlap. The stages are as follows:

- Motivation stage. Created at the time evaluation is needed, formulates a question why evaluation is required;

- Preparatory stage. Develops plans, intents and objectives and formulates conditions or rules;

- Realization stage. Plans are fulfilled, continuously updated and recorded;

- Interpretation stage. Space offered for assessment of collected data and information for a final report, the final report identifies future development priorities;

- Corrective stage. Applies the findings in order to strengthen the existing state;

- Metaevaluation stage. Completes the whole process but also presents an impulse for further evaluation (Poláchová and Vaštatková, 2010).

For the evaluation process to achieve the best results it must meet the ' $4 \mathrm{E}$ '. That is Effectiveness, i.e. things should be done in the right way and should be effectivenessoriented; Efficiency, i.e. the right things should be done in a target-oriented way; Economy, i.e. things should be done for minimum costs; Equity, i.e. things should be done in a responsible, fair and lawful way (Poláchová and Vaštatková, 2010). 


\section{Educational research}

The frequently proclaimed mission of educational research is 'service to education'. This is undoubtedly significant but not the only purpose of the existence of educational research. Another important mission is self-development and thus development of the whole educational science. This means that educational research should carry out activities directed inside the system itself that improve the system's own theory (as research has an own theory and paradigms). At the same time, educational research should develop new methods as a personal and material basis, etc. Any research neglecting the second objective of its own existence ends up stagnating or even in crisis. The reason and purpose of the existence of educational research is thus to produce findings about educational reality for various types of addressees and to carry out activities to propel and improve the system itself.

Educational research is an activity that primarily describes, analyses and also predicts the processes inside the whole educational system with respect to determining conditions - political, demographic, economic but also ideological. Educational research and development includes systematic and original investigation and related developmental aspects:

- Social, cultural, economic and political contexts, in which educational systems function;

- Educational intents;

- Teaching, learning and personal development processes;

- Work of educational employees;

- Organization of educational activities and resources;

- Political procedures and strategies to achieve educational objectives;

- Political, economic, social and cultural outcomes of education (Průcha, 2005).

Educational research is based on the theory that educational science has two components: theory and research. A theory is a sum of concepts, statements, hypotheses, formulated problems, scepticisms, etc. that in a systematic way model a certain part of reality; in case of educational theory they model educational reality. Generally speaking, research is an instrumental apparatus that saturates educational theory with data and findings about a certain reality. Both components are mutually complementary and determining, one cannot properly function without the other should serious science be involved. Professionals involved in educational reality (e.g. teachers) or commenting on educational reality (e.g. inspectors) or deciding on the development or financing (e.g. politicians) have different relationships to both components of educational science. Some tend to overestimate educational theory and regard educational research rather needless; others attribute little significance to educational theory and rather rely on field-based research findings; some can even do without both theory and research. 
The position of educational research varies to a considerable extent between developed countries and the Czech Republic (Prücha, 2005). To clarify the concept of educational research, some description is required. Educational research:

- Is an activity focusing on educational reality;

- Aims to systematically describe, analyse and clarify various phenomena of educational reality;

- Focuses on the objects of educational reality that are of a quality differentiated nature, this implies the existence of various methods and approaches in educational research;

- Is an organized and institutionalized activity and is performed within scientific and other subjects (institutions, associations, information streams, publication media, etc.);

- Is an activity that is practical in essence, i.e. is based on human practice (induced by human practice) and is directed towards such practice through own results and effects;

- As any systematic activity is based on a certain theory, i. e. has a theoretical and practical part (instrumental);

- Has own ethics, i.e. set of moral values and norms that govern professional conduct of those who perform educational research (Průcha, 2005).

However, we must bear in mind that there are certain areas that cannot be addressed by educational research. These include normative issues; production of administrative findings that would immediately respond to the needs of relevant political authorities and educational practitioners, and issuing 'patents' to address various issues in education. On the other hand, there are areas that can be addressed by educational research. These include for example formulation of findings about education by means of basic research. Another option is to formulate questions, identify problems and explain these problems. Educational research can also produce findings that present a resource for policy makers, i.e. findings of an advisory (sometimes disputing) nature. These researchbased findings together with information from other sources present 'a knowledge base' used by policy makers and practitioners (Průcha, 2005).

From a practical viewpoint it is often emphasised that educational science does not have 'a monopoly' on research because research can be performed by other subjects as well, not just professional researchers. The most frequently promoted method is a concept of action research. This concept is explained by Švec et al. (1998) as a type of research, whose primary aim is to instantly improve or alter a partial issue of educational reality (e. g. social climate in a single class). Action research is performed especially by practitioners (teachers, school management employees, etc.) in cooperation or upon consultation with professional researchers. Action research forces professional researchers to think about, in a responsible way, the needs of practical education and about methods of communicating research-based outcomes to the lay public. 
As far as the applicability of the results of educational research is concerned, numerous researchers emphasise that such applicability must be ensured or facilitated by certain activities of the researchers themselves. This particularly concerns the requirements for communicability of research results; directness (i.e. respecting various information needs of individual groups of research users), appropriateness of communication (i. e. respecting the extent and style of presented information), etc. Currently in the Czech Republic there is no scientific body that would focus exclusively and systematically on educational research (the J. A. Komenský Educational Institute, Czechoslovak Academy of Sciences, was closed as a result of reduction of the Academy of Sciences of the Czech Republic). The only nation-wide educational research platform is the Czech Educational Research Association (ČAPV) (Průcha, 2005).

\section{Evaluation of educational research}

Our everyday informal interaction is filled with numerous judgements and assessments that intentionally or unintentionally help classify our social reality. This classification on a good-bad scale, beneficial-harmful scale, etc. comprises a hierarchical principle, which is implicitly based on our conviction. Evaluation research differs from our everyday judgements in that this conviction (most frequently in the position of public policy, scientific discourse, political ideology, etc.) is reflected (Kovár, 2010). The main reason for subjecting educational research to evaluation is that it is a human activity and because other human activates and creations are assessed, not excepting research. For these reasons, research evaluation methods are developed and applied.

Another reason is based on the specific nature of educational research. Educational research, as understood in developed countries and marked as 'research and development' is closely associated with educational practice; therefore, the degree of research advancement and productivity influences various educational policy decisions and approaches applied in everyday school life. For this reason a great deal of support is directed towards educational research and its institutional and financial aspects. Considering the expended funds, it is required that educational research be assessed in terms of quality, productivity, etc. Another specific reason is based in the membership of the Czech Republic in OECD (Organisation for Economic Cooperation and Development) and other international organizations. These organizations now include educational research and development indicators into their evaluation overviews and it might be anticipated that Czech educational research will have to be covered by these indicators (Průcha, 1996). 


\section{Educational evaluation}

In common usage the meaning of the terms education and teaching coincides. These terms generally describe what happens in classrooms between teachers and students on an everyday basis. In professional language, the terms differ in meaning. Some professionals use the terms education and teaching as synonyms, while others use them in different ways. Both terms can be differentiated as follows. Teaching describes activities performed by a teacher, lecturer, etc. during the educational process in an interaction with the subjects of education. A synonymic term would be 'instruction'. Education is a wider term involving teaching (teacher activities), learning (pupil activities) and also the content of these activities, their objectives, conditions, outcomes, etc. An English equivalent to the polysemous term 'education' would be 'educational (instructional) process' (Průcha, 1996). According to Průcha, Walterová and Mareš (2003), this concept is also supported by the Dictionary of Education and is also in accordance with the general didactic concept by Maňák et al. (1994). Assessment of education in terms of conceptual procedures that define and measure effective or ineffective education supports and reproduces a knowledge production system (Magnusson, 2001).

Another interesting issue concerns the methods of exact assessment of the quality (level) of education. In practice this evaluation would usually take the form of inspection. School inspectors or other school management employees would assess schools and teachers, primarily based on lesson observation. This assessment was based rather on intuitive criteria, i. e. own educational experience and visions of an appropriate level of education. Obviously, this type of assessment could not provide precise and reliable data for educational evaluation. Since 1960s in many European countries (and finally also in the Czech Republic) the primary role of school inspection has changed from inspecting to monitoring and advising. At the same time, research instruments have been developed and improved to ensure reliable recording of the course of education (teaching) and its assessment and precise measurement (Průcha, 1996). Evaluation also supports the application of student assessment, verifies acquired knowledge and serves as a significant indicator for improving and measuring the quality of education (Mustafa and Chiang, 2006).

\section{Evaluation methods}

Evaluation methods are sometimes called evaluation instruments or methods of assessing the level of education. An evaluation instrument is a reliable method or technique of data collection for the purposes of own school assessment, or procedures supporting various stages of the evaluation process. There is a large number (up to several hundreds) techniques and procedures of educational evaluation published in professional 
foreign journals or books. These techniques and procedures are specialized according to subjects, grades, age, etc. and it is not easy understand their system. According to a basic approach they can be divided into two large groups: objective (observation) techniques of educational evaluation and subjective (participation) techniques of educational evaluation.

Objective techniques of educational evaluation are based on observation. The observer (researcher or evaluator) is present during classes and uses a recording instrument (record sheet, voice recorder, camcorder, etc.) to record specified parameters of the educational process, e. g. number and type of the teacher's questions, etc. After that, the recorded course of education is analysed and assessed against predetermined criteria, i.e. conclusions are made about the quality of observed education. This method of evaluation is called objective as it maintains the same principle as in observing experiment in natural sciences, where a researcher must not interfere in the course of observed processes and must rely solely on scientifically recordable (measurable) aspects.

Subjective techniques of educational evaluation are based on a different principle reports of class participants on certain educational aspects. This is most frequently teacher self-evaluation (self-reporting), i.e. teacher reports (interviews, diary reports, etc.) on own teaching activities, or pupil reports (or other subjects of education) on how they perceive education. Subjective educational evaluation by pupils has become a part of a wider assessment of educational environments (Průcha, 1996).

Assessment methods must be suitable for a particular process. Quality-based research methods (focus on how individuals and groups view, understand and interpret the world) as well as quantity-based research methods (describe certain phenomena using features designed to measure specific properties) are usually used in general assessment studies. The selection of research methods influences the details of the evaluation process, time and depth of the research (Seasons, 2003).

A specific area of educational evaluation is students' assessment of the quality of university education and the work of university lecturers. This technique primarily uses anonymous scale questionnaires (rating) focusing on individual courses, lecturers, etc. In 1980s this type of evaluation was used in some universities in the USA and elsewhere but later it was no longer used mainly due to increasing tension between assessing students and assessed lecturers. In our country this evaluation method is not used because of the same objections as in foreign countries. Generally speaking, educational evaluation includes a certain degree of imbalance as a majority of evaluation focuses on teacher activities whereas the assessment of student learning activities is rarely performed. The main obstacle might be that the teacher is a single subject whose activities are easily recordable, while the students present a larger or smaller group of subjects, whose individual activities are difficult to record at the same time (Prücha, 1996). A mutual comparison of both approaches raises a question which evaluation techniques are better. However, there is no positive answer that one of the two approaches is better than the other. 
An optimum solution appears a combination of the two. If we want to achieve the most reliable assessment of education, both approaches must be used. If we want to assess the quality (level) of education in a reliable way, a large number of teachers/ lessons must be investigated to offset inter-individual differences in teacher activities. In that case, however, it is unclear what the effect of the 'pupils' variable (classes with various compositions of pupil population) is. Alternatively, we must focus on education in various classes for a longer period of time, which keeps the 'pupils' variable constant and the evaluation process provides more realistic results compared with assessing various isolated lessons in various classes (Průcha, 1996).

\section{Self-evaluation}

The meaning of the term self-evaluation is explained in various ways in the Czech environment. For example in the approved fourth version of the Framework educational programme for basic education (RVP ZV) it is 'systematic assessment of school activities, the results of which are used as feedback for correction of own activities and as a basis for further functioning of the school' (Jeřábek et al., 2007, 110).

Various explanations of the term self-evaluation are found in various sources. For example Nezvalová (2006) according to Roupec explains self-evaluation as a systematically prepared and planned assessment directed towards predetermined objectives according to predefined criteria. Another explanation says that 'self-evaluation can be understood as a mechanism of continuous self-regulation of own educational work' (Rýdl, Horská, Dvořáková and Roupec, 1998, 19). Last but not least self-evaluation is defined as student-assessed quality of student work on the basis of evidence and explicit criteria with a view to produce better work in the future (Ross and Rolheiser, 2000).

The compound term self-evaluation implies own and original evaluation activity performed by the evaluator. An evaluation guide can be a teacher or a school as a whole. With respect to current trends and newly introduced responsibilities specified by the Education Act on producing school annual reports and own school assessment, available literature, with a few exceptions, focuses primarily on school self-evaluation. This requirement urges schools and their employees to jointly speak about the quality of their own work, recognize strengths and weaknesses, analyse mistakes, search for ideas for corrections and improvements, introduce changes. Of course the effort is not to introduce changes at any cost but also to maintain any existing high-quality aspects. Naturally, all these internal processes and external changes are primarily dependent on each individual teacher, who together with other colleagues co-develops and coinfluences the school quality.

The main purpose of self-evaluation is to improve in all areas of educational reality. This process should be carried out continuously (Ďatková, 2009). Some evalua- 
tion techniques take educational data from teacher self-evaluation or self-description (self-reporting). Self-evaluation data are gained from various sources (diary records, self-evaluation questionnaires, interviews, etc.) Self-evaluation techniques also include questionnaires sent through mail (mail survey), verbal or telephone questioning with the same content as written questioning, and teacher diary records that record time profiles of everyday teaching according to specific instructions (Průcha, 1996).

\section{Example of evaluation process}

The Faculty of Physical Culture is one of eight Faculties at Palacký University, Olomouc. The Faculty offers three study programmes; courses are delivered by lecturers from six Departments and one Institute that guarantee specific courses for students.

In the evaluation survey each assessed course was classified according the department where such course is delivered. The evaluation involved full-time as well as combined students. In the pilot study the evaluation covered courses for the academic year of 2011/2012. For this period, a total of 15,022 questionnaires were assessed. The number of assessed courses was 568 (322 courses in winter term 246 course in summer term). In winter term both forms of study involved a total of 93 lecturers, whereas in summer term it was 91 lecturers.

Educational evaluation at the Faculty of Physical Culture is specified by a Dean's methodological guideline that defines the methods of evaluation (Methodological guideline on performing educational evaluation at the Faculty of Physical Culture, Palacký University, Olomouc No. 8/2011) effective as of 3 October 2011. Before the evaluation was commenced the lecturers were informed about the course of evaluation by means of an information leaflet on a noticeboard by the entrance to the Faculty building for the lecturers not to forget to evaluate their course. Upon completion of individual courses, at the end of winter and summer terms, the students were given evaluation questionnaires by their lecturers. This provided sufficient space for evaluation of individual courses.

A significant step to achieve reliable conclusions was that the students filled in the questionnaires anonymously and their answers were used solely for the purposes of evaluation. The evaluation questionnaire consisted of ten questions rated on a scale from 1 (definitely not) to 6 (definitely yes); the students were supposed to indicate the best possible answer on the scale. The questions covered the structured nature and quality of classes and personality and educational qualities of the lecturer. At the end of the questionnaire the students had an opportunity to add a verbal comment in case the questions were insufficient or if they wanted to address a specific issue.

For the academic year of 2011/2012 a total of 15022 evaluation questionnaires were evaluated. In winter term the number in the full-time study was 6070; in the combined 
study 3070 . In summer term the number in the full-time study was 3117 ; in the combined study 2765. The results indicate that the education in Bachelor's and follow-up Master's programmes at the Faculty of Physical Culture is of a high quality level.

At the end of February and June (end of summer term) the heads of the Faculty Departments and the Institute received detailed evaluation results. Specific evaluation results were then communicated to the lecturers and analysed; further procedures or measures to improve the quality of education were proposed. They were also told which departments have outstanding lectures and which lecturers"need to think about their attitude and educational skills" (Dostálová, 2011).

Probably the most significant element of the whole evaluation process was getting feedback for the lecturers, who had an opportunity to find out how their work was assessed by the students. They also learned which positives about their classes or themselves the students liked and what the students believed to be insufficient. Such assessment should not be considered by the lecturers as something negative but rather as an opportunity to improve and move forward in their teaching. Also the heads of departments received information about the quality of education, individual lecturers, educational process and the provision of material conditions.

Each lecturer received the evaluation results for each course with scores for individual questions illustrated by means of a frequency graph, and an overall score. Below the graph space was provided for the students' comments. The lecturers were also informed about the number of students involved in assessing the courses. The results of evaluation of each course could be printed on a standard A4 sheet (number of pages depends on the number of assessing students and number of additional comments). The same information was presented to the heads of the Departments and the Institute.

All evaluated courses were also ordered from the highest to the lowest score for each period separately for each term, specifying the number of evaluation questionnaires for each course. All additional comments were also separately assessed, again for each form of study. The results compared the quality of education by scores and also by comments that were further compared. These results indicated top quality education, average education but there were also issues associated with the position of a specific course, its inclusion in the system of education, content, material provision or directly with the personality of the lecturer (professional expertise, presentation skills, attitude to students, education-related requirements), etc. In the context of all evaluation results for a specific period, the heads of the Departments and the Institute we informed whether they have an 'excellent lecturer' or if there are educational issues. 


\section{Figure 1}

Educational Evaluation Questionnaire, Faculty of Physical Culture, Palacký University, Olomouc

\section{EDUCATION \begin{tabular}{l|l|l} 
Palacky University & $\begin{array}{l}\text { Faculty } \\
\text { olomouc Physical Culture }\end{array}$
\end{tabular} EVAluATION \\ Lecture: \\ Lecturer: \\ $\operatorname{cross}$ Х $\mathrm{A} B \mathrm{~B}, \mathrm{D}, \mathrm{EF}$}

1 Was the lecturer prepared for the class?

2 Was the lecture systematic?

Was time used in an effective way?

3 Was the lecturer's presentation clear and comprehensible?

4 Did the lecturer use modern teaching methods and modern aspects of the course?

5 Did you feel the lecturer was an expert in the subject?

6 Did the lecturer provide an appropriate amount and type of information?

7 Was taking the lecture of a benefit to you?

8 Did the lecture have a positive atmosphere?

$9 \mid \begin{aligned} & \text { Was the lecturer's attitude } \\ & \text { to the students fair? }\end{aligned}$

10| How would you assess the course overall?

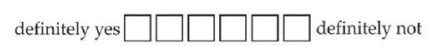

definitely yes $\square \square \square \square \square \square$ definitely not definitely yes $\square \square \square \square \square \square$ definitely not definitely yes $\square \square \square \square \square \square$ definitely not definitely yes $\square \square \square \square \square \square$ definitely not definitely yes $\square \square \square \square \square \square$ definitely not definitely yes $\square \square \square \square \square \square$ definitely not

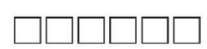

Personal comments:

Thank you for filling in this evaluation questionnaire. 


\section{Evaluation prospects}

With respect to the need for objective assessment of the real state of education, theoretical explanation of this state and development of a basis for practical measures, evaluation surveys, through which required data on the quality of education, departments, courses and lecturers are obtained, will be carried out in future on a regular basis. From a long-term perspective, various periods can be compared and the development in terms of quality and excellence can be monitored.

Regarding the fact that the evaluation process is of a dynamic nature and constantly develops, some survey questions have been reformulated or particularized and some formal and graphical adjustments to the evaluation questionnaire have been performed. The question that remains is the number of survey questions, whether ten is enough to cover all aspects. There are also other issues such as more detailed assessment, processing and last but not least higher printing costs.

Another significant aspect after a certain period of the evaluation process is a decreased level of students' cooperation in completing evaluation questionnaires for a large number of courses, which is visible towards the end of the evaluation period. Other limitations include the time that elapses from data collection through a detailed analysis, submission of results and publication of the evaluation report. Collection of evaluation questionnaires is always completed on a specific date; questionnaires submitted after this date are included in evaluation for the following period. An issue is the return rate of record sheets towards the end of the evaluation period, which often concurs with completion of the course and an exam. A solution could be an electronic evaluation system, however, there are also some specifics and issues.

\section{Conclusion}

The theoretical background of evaluation points to a need for evaluating empirical data in order to obtain required information that can be directly applied in practical environments. The purpose is to cover the whole educational process and, based on a detailed analysis, revise and innovate the educational system. A specific area of education is assessment of the quality of university education and the work of university lecturers. On a specific example of an analysis of the evaluation process at the Faculty of Physical Culture we covered the main features and specifics of university evaluation. The analysis was performed using an evaluation survey consisting of ten questions. The results were mainly positive. The purpose of this pilot study was to demonstrate that in the long run the development of the whole educational system cannot do without thorough and scientifically based evaluation surveys that not only objectively show 
the real state of education but can also theoretically explain this state and develop a basis for practical measures.

\section{Acknowledgements}

This article is a part of the project "Physical Activity and Inactivity of the Inhabitants of the Czech Republic in the context of Behavioral Changes (No. MSM6198959221) supported by the Ministry of Education, Youth and Sports of the Czech Republic.

\section{References}

Byčkovský, P. (1982). Základy měření výsledků výuky. Praha: Výzkumný ústav inženýrského studia. Dostálová, I. (2011). Závěrečná zpráva z evaluace výuky na FTK UP za zimní semestr 2011 [Závěrečná zpráva]. Olomouc: Univerzita Palackého, Fakulta tělesné kultury.

Ďatková, J. (2009). Autoevaluace učitele a její metody. Diplomová práce, Masarykova univerzita, Pedagogická fakulta, Brno.

Gard, C. L., Flannigan, P. N., \& Cluskey, M. (2004). Program Evaluation: An Ongoing Systematic Process. Retrived 22. 7. 2012 from PRO QUEST database on the World Wide Web: http://search.proquest. com/docview/236601833/13814FB756B3AC84FE0/6? accoun tid=16730

Janík, T., Knecht, P. \& Najvar, P. et al. (2010). Nástroje pro monitoring a evaluaci kvality výuky a kurikula. Brno: Paido.

Jeřábek J. et al. (2007). Rámcový vzdělávací program pro základní vzdělávání. Retrieved 22. 7. 2012 from World Wide Web: http://www.vuppraha.cz/wp-content/ uploads/2009/12/RVPZV_2007-07.pdf

Kovář, J. (2010). Evaluační výzkum Retrieved 11. 5. 2012 from World Wide Web: http://antropologie. zcu.cz/evaluacni-vyzkum

Kudláček, M. (2011). Metodický pokyn k provádění evaluace výuky na FTK UP [8/2011]. Olomouc: Univerzita Palackého, Fakulta tělesné kultury.

Magnusson, J. L. (2001). The evaluation of university teaching: exploring the question of resistance. Retrived 22. 7. 2012 from PRO QUEST database on the World Wide Web: http://search.proquest. com/docview/194891209/fulltext/13813C9D9014E9B2E3C/2?accountid=16730

Maňák, J. et al. (1994). Kapitoly z metodologie pedagogiky. Brno: Masarykova univerzita.

Mustafa, S. T., \& Chiang, D. (2006). Dimensions of Quality in Higher Education: How Academic Performance Affects University Students' Teacher Evaluations. Retrived 22. 7. 2012 from PRO QUEST database on the World Wide Web: 43 http://search. proquest.com/docview/222843183/ 13813E2493C63B8F24E/2?accountid=16730

Nezvalová, D. (2006). Pedagogická evaluace. Retrieved 13. 3. 2012 from World Wide Web: http:// clanky.rvp.cz/clanek/c/Z/963/pedagogicka-evaluace.html/

Perspektivy kvality (2009). Metodika pro interní hodnocení škol podle modelu CAF CZ. Retrieved 16. 4. 2012 from World Wide Web: http://www.perspektivykvality.cz/nastroje-a-metody/metodika-pro-interni-hodnoceni-skol-podle-modelu-caf-cz-2009.html

Poláchová Vaštatková, J. (2010). Úvod do pedagogické evaluace a jejích metod. Olomouc: Univerzita Palackého.

Průcha, J. (1995). Pedagogický výzkum. Uvedení do teorie a praxe. Praha: Karolinum. 
Průcha, J. (1996). Pedagogická evaluace. Brno: Masarykova univerzita, Centrum pro další vzdělávání učitelů.

Průcha, J. (2000). Přehled pedagogiky. Praha: Portál.

Průcha, J., Walterová, E., \& Mareš, J. (2003). Pedagogický slovník. Praha: Portál.

Průcha, J. (2005). Moderní pedagogika. Praha: Portál.

Ross, J. A., \& Rolheiser, C. (2000). Student self-evaluation: what do we know?. Retrived 22. 7. 2012 from PRO QUEST database on the World Wide Web: http://search. proquest.com/docview/ 213737675/13814FB756B3AC84FE0/23?accountid=16730

Rýdl, K., Horská, V., Dvořáková, M., \& Roupec, P. (1998). Sebehodnocení školy. Praha: STROM a. s.

Scriven, M. (1991). Evaluation Thesaurus. Newbury park: Sage.

Seasons M. L. (2003). Monitoring and evaluation in municipal planning. Retrived 1. 4. 2014 from PRO QUEST database on the World Wide Web: http://search. proquest. com/docview/229730226/ 13814FB756B3AC84FE0/36?accountid=16730

Švec, Š. et al. (1998). Metodológia vied o výchove. Kvantitativno-scientické a kvalitativno-humanitné prístupy v edukačnom výskume. Bratislava: IRIS - Vydavatel'stvo a tlač, s.r. o.

\section{Contact:}

RNDr. Iva Dostálová, Ph.D.

Faculty of Physical Culture, Palacký University Olomouc

Tř. Míru 115, 77111 Olomouc

Czech Republic

E-mail: iva.dostalova@upol.cz, Phone: +420-585 636152

doc. PhDr. Zbyněk Svozil, Ph.D.

Faculty of Physical Culture, Palacký University Olomouc

Tř. Míru 115, 77111 Olomouc

Czech Republic

E-mail: zbynek.svozil@upol.cz, Phone: +420-585 636001

PhDr. Martin Sigmund, Ph.D.

Faculty of Physical Culture, Palacký University Olomouc

Tř. Míru 115, 77111 Olomouc

Czech Republic

E-mail: martin.sigmund@upol.cz, Phone: +420-585 636157

PhDr. Jana Kvintová, Ph.D.

Faculty of Education, Palacký University Olomouc

Žižkovo nám. 5, 77140 Olomouc

Czech Republic

E-mail: jana.kvintova@upol.cz, Phone: +420-585 635203

Bc. Jan Baše

Faculty of Physical Culture, Palacký University Olomouc

Tř. Míru 115, 77111 Olomouc

Czech Republic 